\title{
Evaluation of the Water Producer Project in the preservation areas OF THE HYdRographic BaSIN OF THE CAMBoriú RIVER BRAZIL
}

\author{
Paulo Henrique Santos ${ }^{1 *}$, Paulo Ricardo Schwingel ${ }^{1}$
}

\author{
${ }^{1}$ Universidade do Vale do Itajaí, Santa Catarina, Brasil \\ *CorrespondingAuthor: santosph14@yahoo.com.br
}

Recebido em 13 de janeiro de 2019. Aceito em 04 de julho de 2018. Publicado em 31 de julho de 2019.

\begin{abstract}
The Camboriú River Basin (BHRC) supplies the municipalities of Balneário Camboriú and Camboriú (Brazil). The lack of public policies, such as sanitation, has impacted the quality water Faced with the growing need for water, the National Water Agency developed the Water Producer Program, aiming to increase the quantity and quality of water in watersheds. Based on this program, the Water Producer (PA) project was created at the BHRC in 2009. The objective of this study is to evaluate the PA in the areas of preservation of the BHRC in 2013 to 2017 period. The contracts between the Grantor and Landowners, survey reports, as well as on-site assessments was analyzed. The analysis demonstrated $81.25 \%$ of the contracts were renewed, $55.6 \%$ of the partner institutions have effectively participated in the surveys and $88.9 \%$ are present at the meetings of the Management Group. By 2017, 39.11 ha were restored, representing $7.82 \%$ on the target set by the project. The success of PA is associated with a permanent monitoring and evaluation, allowing greater transparency and corrections in the use of financial resources and management strategies.
\end{abstract}

KEY WorDs: Camboriú River basin, Water Producer Project, Survey and Inspection Report.

Avaliação Do Projeto Produtor De Água Nas Áreas De Preservação Da Bacia Hidrográfica Do Rio Camboriú - BrasiL

Resumo - A Bacia Hidrográfica do Rio Camboriú (BHRC) abastece os municípios de Balneário Camboriú e Camboriú (Brasil). A falta de políticas públicas, como o saneamento básico, tem impactado a qualidade deste recurso. Diante da crescente necessidade de água, a Agência Nacional de Águas desenvolveu o Programa Produtor de Água, tendo como meta aumentar a quantidade e qualidade da água nas bacias hidrográficas. Baseado neste programa, foi criado o projeto Produtor de Água (PA) na BHRC em 2009. O presente trabalho tem o objetivo de avaliar o PA nas áreas de preservação da BHRC no período de 2013 a 2017, sendo analisados os contratos realizados entre a Concedente e os Proprietários Rurais, relatórios de vistorias, bem como avaliações in situ. A análise demostrou que $81,25 \%$ dos contratos foram renovados, $55,6 \%$ das instituições parceiras tem participado de forma efetivas nas vistorias e 88,9\% estão presentes nas reuniões do Grupo Gestor. Até o ano de 2017 foram restaurados 39,11 ha, representando 7,82\% da meta estabelecida pelo projeto. O sucesso do PA está associado a um permanente monitoramento e avaliação, possibilitando maior transparência e correções no uso dos recursos financeiros e estratégias de gestão.

Palavras-Chave: Bacia Hidrográfica do Rio Camboriú, Projeto Produtor de Água e Relatório de Vistoria.

Evaluación Del Proyecto Productor De Agua En las Áreas De Preservación De la Cuenca Hidrográfica Del Río Camboriú - Brasil

Resumen - La Cuenca Hidrográfica del Río Camboriú (BHRC) abastece a los municipios de Balneário Camboriú y Camboriú (Brasil). La falta de políticas públicas, como el saneamiento básico, ha impactado en la calidad de este recurso. Ante la creciente necesidad de agua, la Agencia Nacional de Aguas desarrolló el Programa Productor de Agua, teniendo como meta 
aumentar la cantidad y calidad del agua en las cuencas hidrográficas. En base a este programa, se creó el proyecto Productor de Agua (PA) en la BHRC en 2009. Este trabajo tiene el objetivo de evaluar el PA en las áreas de preservación de la BHRC en el período de 2013 a 2017, siendo analizados los contratos realizados entre la Concedente y los Propietarios Rurales, informes de inspecciones, así como evaluaciones in situ. El análisis demostró que el 81,25\% de los contratos fueron renovados, el $55,6 \%$ de las instituciones asociadas ha participado de forma efectiva en las inspecciones y el 88,9\% están presentes en las reuniones del Grupo Gestor. Hasta el año 2017 fueron restaurados 39,11 ha, representando el 7,82\% de la meta establecida por el proyecto. El éxito del PA está asociado a un permanente monitoreo y evaluación, posibilitando mayor transparencia y correcciones en el uso de los recursos financieros y estrategias de gestión.

Palabras-Clave: Cuenca Hidrográfica del Río Camboriú, Proyecto Productor de Agua e Informe de Inspección.

\section{INTRODUCTION}

When the first Europeans arrived in Brazil in 1500, the Atlantic Forest covered about 15\% of the Brazilian territory, which would now correspond to 17 Brazilian states. Currently, only $7.3 \%$ of the original coverage in fragments larger than 100 hectares. Traditional communities, rural and urban populations rely heavily on environmental services that the Atlantic provides in regional and global scopes. Projections indicate that losses in the environmental services provision will affect several human groups, with negative impacts, especially for the poorest populations (MMA 2011).

A report of Bennetti et al. (2012) shows that there were 205 active environmental programs around the world, covering an area of approximately 117 million hectares. In Latin America, Colombia was the first nation to promote public policies, as Payments for Environmental Services (PES) in the Valley of the Cauca River Valley in the decade of 1990 (Blanco et al. 2008). On the other hand, Costa Rica is one of the most advanced countries in terms of public policies for environmental protection, through the PES mechanism (Bernades et al. 2010).

In Brazil, the implementation of the PES public policy has become relevant with the Native Vegetation Protection Law No. 12.651/2012 (BRASIL, 2012), which authorized the federal Government to establish programs to encourage and support the conservation of ecosystems. The expansion of the PES in the country has spawned numerous policies of this nature at regional and local levels (FGB/TNC/MMA/GIZ 2017). The National Water Agency (ANA), in partnership with other institutions, has been developing the Water Producer Program (PPA), a tool for the improvement, recovery and protection of water resources in strategic river basins. The PPA is based on actions performed in rural areas aimed at reducing erosion and silting up water sources, increasing the quality and regularity of water supply (ANA 2008). The PPA uses the public policy PESPES as an instrument of incentive to rural owners voluntarily commit on the conservation of water and soil.

In the last 15 years, several experiences have used the concept of PES in Brazil, among them it can be mentioned the Conservative project of Extrema/MG, a pioneering project in the country, the Ecocredit program in Montes Claros (MG) and the Waterfall Oasis project of the Metropolitan Region of São Paulo (SP) (ANA 2012). In the State of Santa Catarina, three projects are in progress: Environmental Management Program of the Water Resources Region - SOS Nascentes, in Joinville municipality; Quiriri Municipal Consortium, in São Bento do Sul, Rio Negrinho, Corupá and Campo Alegre municipalities, and the Water Producer (PA) project in the Camboriú River Basin (BHRC) (MMA 2011).

The main objective of the PA in BHRC is to ensure the conservation of water resources in the basin, encouraging the owners to adopt conservation practices in their properties, which involves the recovery of degraded areas, conservation of remaining native forests, the proper management and conservation of rural roads (Santos and Schwingel 2017). At the same time, the Ministry of Environment (2011) states that it is necessary the monitoring of programs using the PES public policy, because they often do not accomplish their objectives, as they are not 
monitored adequately, undermining its credibility. Thus, the objective of this study is to evaluate the effects of Water Producer Projects in preservation areas, taking as a case study the project Water Producer in the Camboriú River Basin in the south of Brazil.

It is important to highlight the relevance of this article to the scientific community and society, since relatively few studies were conducted on the subject. The conservation of water resources demands a favorable economic situation of the institutions that use these public policies, since the recovery of degraded areas have a high cost, even with great results for the environment. The success of conservation areas of the hydrographic basin as result of perform Water Producer Project was not evaluated in Brazil. From this analysis it will be possible to improve PA performance, as well as the use of financial resources for its maintenance.

\section{MATERIAL AND METHODS}

The Camboriú River Basin (BHRC) drains an area of approximately $200 \mathrm{Km}^{2}$, and the Camboriú River has about 40 $\mathrm{km}$ long and bathes the municipalities of Balneário Camboriú and Camboriú (SC). About $90 \%$ of the springs that make up the Camboriú River basin are located in the city of Camboriú. The relief of the basin is characterized by two units, coastal plains and Serra do Tabuleiro, which presents steep slopes and deep valleys with sedimentary deposits of sand-clay and quartz sand. These particular characteristics favor processes of erosion in deforested areas, as well as landslides. The PA project intervention area, located upstream of the BHRC, is approximately $138 \mathrm{~km}^{2}$, corresponding to about $70 \%$ of the entire area of the basin (Antunes et al. 2007) (Figure 1).

The effects of the Water Producer project in the preservation areas of the BHRC were analyzed in the period from 2013 to 2017, on two aspects: a) the contracts established between the rural producers and the grantor, which includes the duties and rights of the owners; and b) surveys conducted. The analysis of each contract included date, term, year, restoration areas, conservation areas inside and outside the Permanent Preservation Areas (PPAs), tracts (lots of land) and amounts paid through PES. Regarding the properties, the observed aspects were: geographical location; locale; number of springs; investments required; type of supply and productivity. Also, regarding the productivity aspect, activities such as livestock, agriculture, ecotourism and stone and macadam extraction are observed. With the information collected in each contract was built chart of the number of new contracts, renewed and canceled. Evaluating the recovery and conservation costs of each area was carried out from the data inserted in the contracts, allowing the control of the resources used in the PA project.

Figure 1. Location of the Camboriú River Basin and the operation area of the Water Producer Project (Brazil Santa Catarina).

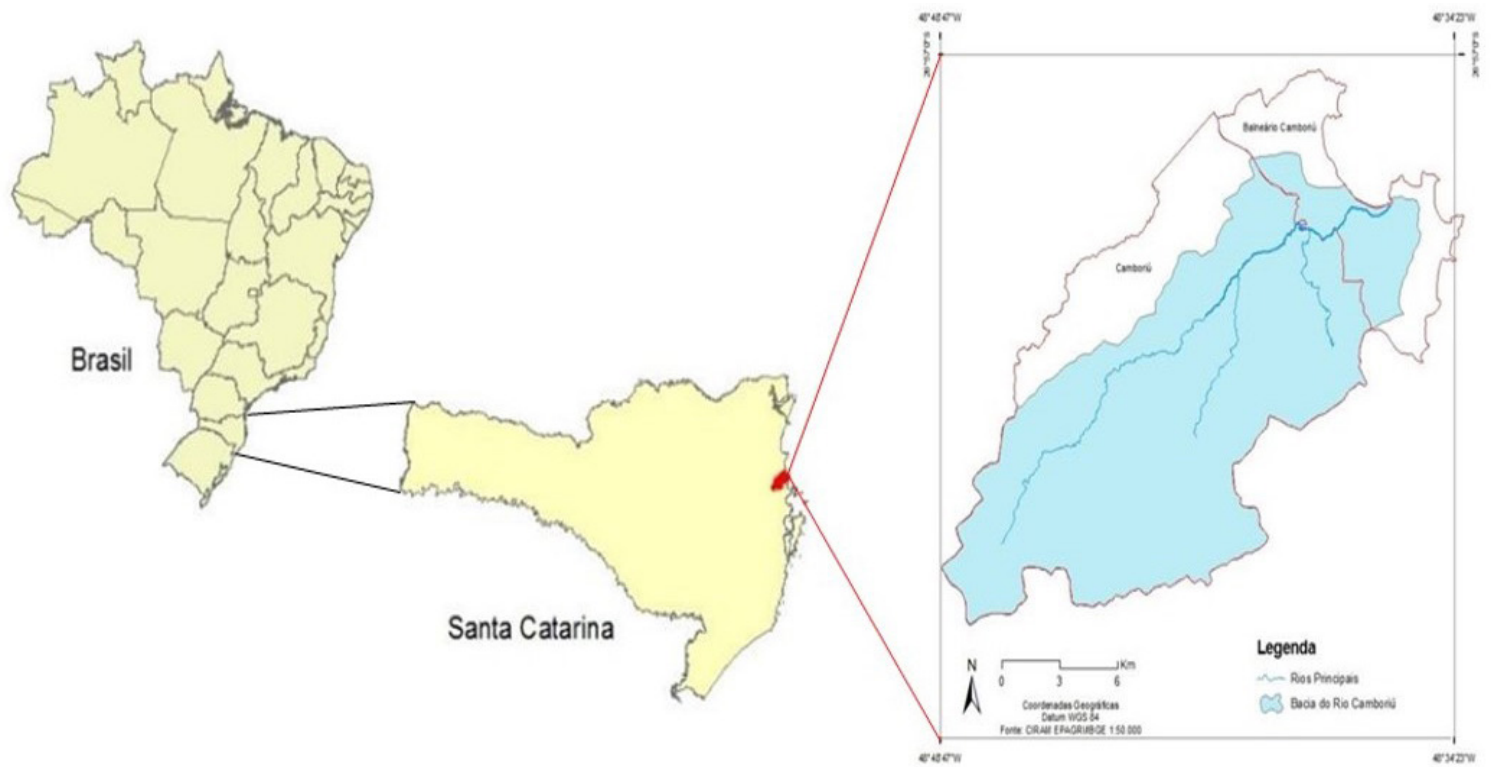


In the surveys the reports were analyzed participation of partner institutions in the meetings of the Management Group (GG) and in the surveys, and graphs were constructed to demonstrate these analyzes, for each partner institution the involvement in the surveys and meetings of the Manager Group was analyzed, institutions dedicate more to the PA project. In the survey reports were analyzed the compliance of actions and goals related to PA project interventions were verified, with the results observed in situ (i.e. protection, recovery of vegetation inside and outside the riparian forests and the participation of partner entities in the project).

\section{RESUlTS AND DISCUSSION}

The contracts of the Water Producer (PA) project in the Camboriu River Basin (BHRC), held between the grantor (Municipal Water and Sanitation Company - EMASA) and rural producers were of two years until 2016, subsequently passed to five. The contracts are based on Municipal Law No. 3026, November 26, 2009 and the Municipal Decree No. 6121, of May 16, 2011, and the list of documents is arranged in draft document "Edital de Chamamento 01- 2016" (Santos 2018).

The PA Project aims to contribute with the landowner, providing opportunities for increasing family income, preserving and restoring the environment. The financial benefit obtained through the PES does not cover property costs, being necessary to maintain other activities. The analysis of the contracts demonstrated that in the early years (2013-2015) of the PA project there was stability in membership numbers, where in the following years (20162017) showed decline of accessions (Figure 2-A). The lack of planning in 2015 with only one annual meeting (Figure 2-B), the departure of the executing company of the project in 2016 and the operation being assumed by the grantor, may have determined the decline in accessions from 2016.

Figure 2. A. Agreement number of the Camboriú-SC River Basin Water Producer project from 2013 to 2017. B. Number of meetings (quarterly) of the Management Group in the years 2012 to 2017 of the Camboriú-SC River Basin.

A

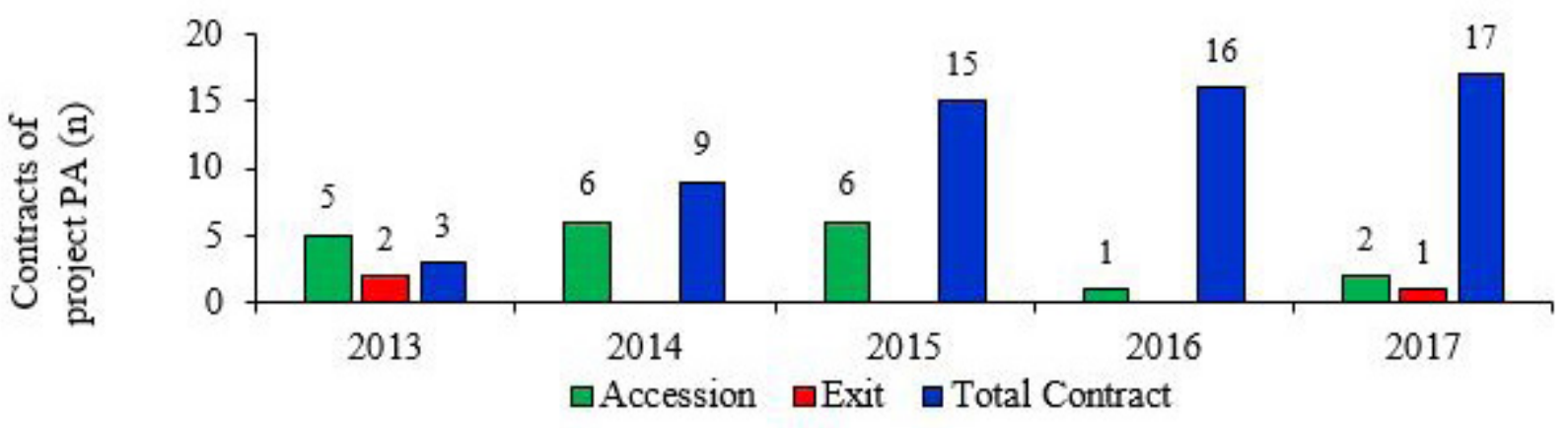

B

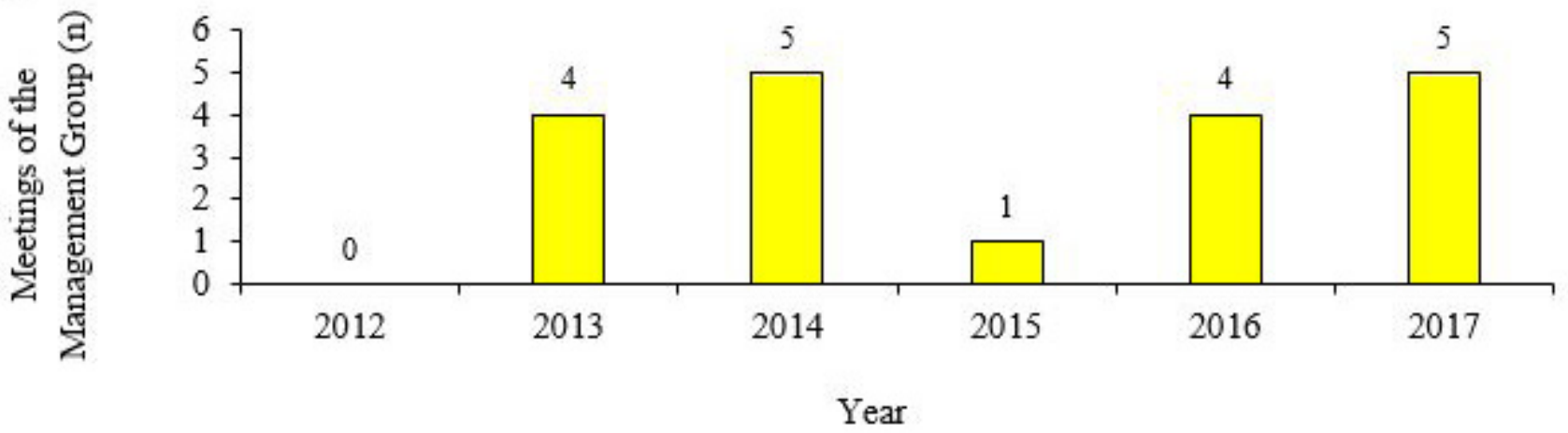


On the other hand, it was possible to observe that both the landowners as the grantor are complying with the contracts, a fact that was evidenced by the high rate of contract renewal $(81.25 \%)$. The renewal is only performed if the landowner is complying with the objectives established in the contracts, i.e., protection and restoration of riparian forests. The parceling of the soil in the project area PA, was the reason they were not renewed $12.5 \%$, and the cancellation of a contract $(6.25 \%)$ was due to death of an owner (Table 1).

Table 1. Signature dates of the 1st and 2nd contracts (renewal) of the Water-producer project of the Rio Camboriú (SC) water basin between 2013 and 2017.

\begin{tabular}{|c|c|c|c|c|c|}
\hline \multirow{2}{*}{ Property code } & \multicolumn{2}{|c|}{ Date } & \multirow{2}{*}{ Property code } & \multicolumn{2}{|c|}{ Date } \\
\hline & first contract & second contract & & first contract & second contract \\
\hline PR 0017 & $06 / 03 / 2013$ & $18 / 06 / 2016$ & PR 0101 & $13 / 03 / 2013$ & Not renewed \\
\hline PR 0019 & $16 / 10 / 2014$ & $26 / 10 / 2016$ & PR 0109 & $15 / 07 / 2015$ & $14 / 07 / 2017$ \\
\hline PR 0029 & $25 / 06 / 2015$ & $14 / 07 / 2017$ & PR 0299 & $30 / 01 / 2014$ & $30 / 01 / 2016$ \\
\hline PR 0034 & $25 / 06 / 2015$ & $14 / 07 / 2017$ & PR 0300 & $25 / 06 / 2015$ & Canceled \\
\hline PR 0047 & $15 / 03 / 2013$ & 06/03/2017 & PR 0301 & $25 / 06 / 2015$ & $14 / 07 / 2017$ \\
\hline PR 0059 & $09 / 06 / 2014$ & $18 / 06 / 2016$ & PR 0302 & $10 / 08 / 2015$ & 10/08/2017 \\
\hline PR 0063 & $16 / 10 / 2014$ & $27 / 09 / 2016$ & PR 0304 & $14 / 07 / 2016$ & Unfinished \\
\hline PR 0064 & $16 / 10 / 2014$ & $27 / 09 / 2016$ & PR 0305 & $16 / 01 / 2017$ & Unfinished \\
\hline PR 0065 & $05 / 09 / 2013$ & Not renewed & PR 0306 & $28 / 07 / 2017$ & Unfinished \\
\hline PR 0073 & 05/03/2013 & 06/03/2017 & & & \\
\hline
\end{tabular}

In the analysis of the contracts it was also possible to observe that the PES BHRC is developed based on the following indicators: protection of riparian forests and springs covered with native vegetation; protection of areas with native vegetation cover; restoration of degraded areas in riparian forests and springs; and restoration of degraded areas outside riparian forests or springs. The financial value granted to rural owners is determined according to the type of environmental service provided in the property, ranging from 0.5 to 1.5 Municipal Tax Unit (Antunes 2017).

Financial support is proportional to the conservation and restoration actions defined in the Individual Property Project (PIP , in the Portuguese acronym), which is based on the georeferenced cartographic base of Grantor, which includes: a) mapping of properties (property boundaries, bodies of water and springs, roads mapping, mapping of remnants native vegetation and areas for restoration); b) environmental characterization properties (remaining vegetation classification into the following categories: pioneer vegetation, vegetation in primary stage of regeneration and secondary stage of regeneration, medium or advanced); c) actions of environmental suitability defining areas of riparian forests and springs or other areas to be retrieved and d) indication of native vegetation areas determined to conservation.

The PA Project is financed with the grantor's own resources, municipality of Balneário Camboriú. In 2017, through Ordinary Law Project No. 140/2017-EME4, the City Council of Balneário Camboriú modified the text establishing the value allocated to "environmental preservation and recovery programs" to "Water Producer", with this the PA Project between 2018 and 2022 will have exclusivity on the percentage of 1\% of the gross collection of the Grantor. Gross revenues from the Grantor for environmental projects in 2017 was $\mathrm{R} \$ 785,047.96$. Despite this value have increased year after year, the value for the PES, as the goals of the PA project are achieved, will not be sufficient to pay all the benefits. If all financial resources were only used to pay the benefits, the PA project would reach between 50\% and 60\% (Santos 2018). The payment of benefits is not the only cost of the project, and the amount paid to rural producers through the PES is estimated at about $10 \%$ of the initial cost (TNC 2017).

The investment in the form of PES for the payment of benefits to rural producers was R\$129,853.24 in 2017 (Table 2). Data from the Transparency Portal of the grantor of 2016, about the bidding $n^{\circ} 74 / 2016$, reported that 
were employed for restoration services and delimitation of areas through fencing in the area of expertise of the PA project - the amount of $\mathrm{R} \$ 244,981.82$ for an area of 11.15 ha representing a cost of $\mathrm{R} \$ 21,612.00 / \mathrm{ha}$. On the bidding No. 21/2016 maintenance services were hired in the area of restoration in the amount of $\mathrm{R} \$ 168,000.00$ to 23.309 ha, representing a cost of $\mathrm{R} \$ 7,207.33 /$ ha (Santos 2018).

Table 2. The area of conservation and restoration of the Water Producer project and the annual cost payment for environmental services in the Camboriú River basin (SC) to the year of 2017. Note: UFM = Municipal Fiscal Unit of the city of Camboriú was $\mathrm{R} \$ 267.53$.

\begin{tabular}{|c|c|c|c|c|c|c|c|c|c|}
\hline \multirow{2}{*}{ 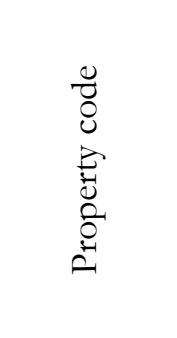 } & \multirow{2}{*}{ 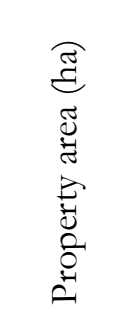 } & \multirow[b]{2}{*}{$\begin{array}{l}\frac{7}{5} \\
\frac{\pi}{0} \\
\frac{1}{1} \\
\vec{B}\end{array}$} & \multicolumn{2}{|c|}{$\begin{array}{l}\text { Conservation } \\
\text { area (ha) }\end{array}$} & \multicolumn{2}{|c|}{$\begin{array}{l}\text { Restoration } \\
\text { area (ha) }\end{array}$} & \multicolumn{2}{|c|}{$\begin{array}{l}\text { Area in the } \\
\text { project (ha) }\end{array}$} & \multirow{2}{*}{$\begin{array}{l}\text { Cost / R\$ } \\
\text { 丞 } \\
\text { 表 }\end{array}$} \\
\hline & & & 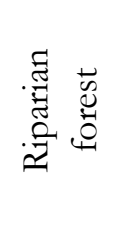 & 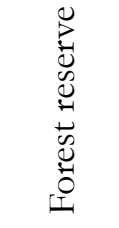 & 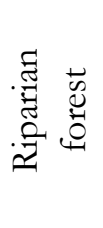 & 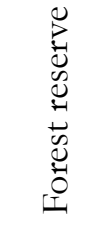 & 趗 & $\stackrel{\partial}{a}^{\circ}$ & \\
\hline PR 0017 & 42.06 & \multirow{16}{*}{ 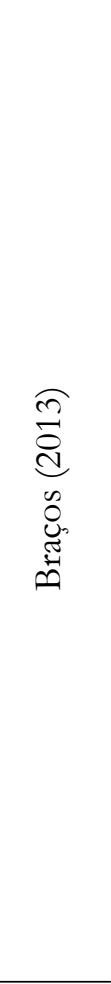 } & 10.57 & 27.43 & - & - & 38.01 & 90.4 & $7,912.55$ \\
\hline PR 0047 & 8.86 & & 1.45 & 6.94 & - & 0.48 & 8.86 & 100.0 & $1,701.45$ \\
\hline PR 0073 & 21.70 & & 7.82 & 7.88 & 0.74 & 0.43 & 16.86 & 77.7 & $4,658.81$ \\
\hline PR 0299 & 29.24 & & 2.55 & 15.88 & - & 3.99 & 22.43 & 76.7 & $4,750.68$ \\
\hline PR 0182 & 81.68 & & 26.91 & 35.03 & - & - & 61.94 & 75.8 & $15,484, .4$ \\
\hline PR 0059 & 255.88 & & 42.73 & 49.52 & 10.99 & 19.76 & 123.00 & 48.1 & $36,112.00$ \\
\hline PR 0063 & 7.72 & & 1.25 & 0.60 & - & - & 1.85 & 24.0 & 582.01 \\
\hline PR 0064 & 12.40 & & 0.40 & 0.75 & - & - & 1.15 & 9.3 & 259.89 \\
\hline PR 0019 & 74.64 & & 10.13 & 55.56 & 0.31 & 1.56 & 67.57 & 90.5 & $12,249.93$ \\
\hline PR 0301 & 21.97 & & 3.16 & 1.50 & - & - & 4.66 & 21.2 & $1,467.76$ \\
\hline PR 0029 & 4.62 & & 1.77 & 1.36 & - & - & 3.13 & 67.7 & 892.99 \\
\hline PR 0034 & 51.28 & & 8.96 & 21.33 & - & - & 30.28 & 59.1 & $6,447.77$ \\
\hline PR 0109 & 22.61 & & 3.46 & 2.14 & 0.27 & 0.01 & 5.87 & 26.0 & $1,785.40$ \\
\hline PR0302 & 30.00 & & 11.80 & 16.15 & 0.57 & - & 28.52 & 95.1 & $7,123.28$ \\
\hline PR0306 & 5.20 & & 0.02 & 0.59 & - & - & 0.61 & 11.7 & 87.23 \\
\hline $\begin{array}{c}\text { Subtotal - } \\
\text { Braços }\end{array}$ & 669.87 & & 132.96 & 242.07 & 12.88 & 26.23 & 414.74 & 61.9 & $101,515.89$ \\
\hline PR0304 & 129.60 & \multirow{3}{*}{ 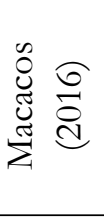 } & 33.69 & 87.72 & - & - & 121.40 & 93.7 & $25,251.29$ \\
\hline PR0305 & 15.64 & & 4.77 & 8.75 & - & - & 13.52 & 86.5 & $3,086.07$ \\
\hline $\begin{array}{l}\text { Subtotal - } \\
\text { Macacos }\end{array}$ & 145.24 & & 38.46 & 96.46 & - & - & 134.92 & 92.9 & $28,337.35$ \\
\hline Total & 815.11 & & 171.42 & 338.53 & 12.88 & 26.23 & 549.66 & 67.4 & $129,853.24$ \\
\hline
\end{tabular}

The cost for restoration and maintenance of one hectare is $R \$ 29,178.79$ with enclosure and $R \$ 13,758.98$ without it. As the goal of the project is to restore 500 ha, the total investment would be approximately $\mathrm{R} \$ 14,600,000$ with fencing and $\mathrm{R} \$$ 6,900,000 without it, based on 2016 values. Until December 2017 were restored 39.11 ha, representing $7.82 \%$ of the target. These data point to the need for greater investments in the project, whether in the form of tariff or public-private investment. A study carried out by Antunes et al. (2017) pointed out that it is necessary to review the PES values, because for some properties profitability with agricultural activity is higher than the amount paid. Since the creation of the PA project, the amounts paid by the PES have not been reviewed 
based on the market value, only some adjustments were made through the UFM. This fact may discourage owners adhere to the AP, making it difficult to meet the project goals.

In the analysis of the surveys it was observed that the 2016 "Call for Proposals" of the grantor establishes that the supervision and management of the PA project is in charge of the same. In addition, the inspection, verification and certification of actions shall be made by the project Inspection Team, to be designated by the Project Manager (GG) of the PA project (Santos and Schwingel 2017). In 2017, the Management Group (GG) was composed of an Executive Secretary, with the positions of the Board, Deputy Director and Secretary, constituted by the institutions: Grantor, the Camboriú River Committee and the Camboriú City Hall, represented by the Camboriú Environment Foundation (FUCAM). The other institutions, The Nature Conservancy (TNC), Public Services Regulatory Agency of Santa Catarina (ARESC), National of Water Agency (ANA), Sanitation Services Regulatory Agency of the state of Santa Catarina (AGESAM), Agricultural Research and Rural Extension of Santa Catarina (EPAGRI), Federal Institute of Education, Science and Technology of Santa Catarina (IFC) and Institute of Environmental Integration and Development (IDEIA) were part of $G G$ as partner institutions.

In the contract signed between the Grantor and Rural Producers it was established that the periodicity of the surveys would be semi-annual, being performed in situ by a team composed of three partner institutions. After inspection, the team prepares the Inspection Report certifying compliance (or not) about the actions defined in the contract. Based on the report, the GG evaluates the attendance of the contract terms, sending a position about it to the Grantor, opining or not for payment. In view of the opinion, the Grantor approves or not and authorizes the payment of the portion corresponding to the environmental services provided by the landowners.

Santos and Schwingel (2017) after analyzing the Survey Reports and in situ observations, identified a more social role than inspection, lack of procedure for surveys and qualification of surveyors. Thus, the authors presented a proposal to guide the surveys, including new report model with Check List of performance control, contributing to the management of Water Producer projects. This new model of Inspection Report was adapted and inserted into the PA project by GG in 2017, with nine reports being prepared this year.

The analysis of the records of GG meetings and survey reports showed low participation of PA partner institutions, considering what was established in the Technical Cooperation Agreement. Of the nine institutions that are part of the PA project four, which represent $44.4 \%$, participated little in the surveys (Figure 3-A), however, eight partner institutions were often present at GG meetings (Figure 3-B), representing almost $90 \%$ of this, this high percentage demonstrates the institutions commitment to the PA project and facilitates decision making by the Management Group. The participation of members, both government and civil society, encourages decision-making and conflict resolution (Victorino 2003).

Analysis of the contracts and the inspection reports demonstrated that the interventions carried out in the area of preservation, with regard to conservation and restoration, are being executed as established in the contracts between the Grantor and Rural Owners. The PA project, such as water resources management, will succeed when two factors are present, the involvement of all in decision-making and the concept of nature conservation is rooted among the participants (Everard and Powell 2002). 
Figure 3. A. Frequency of participation of the institutions in the survey (1st to 45th) of the Camboriú River Basin Water Producer project, within the Technical Cooperation Agreement of 2012. B. Participation of the institutions in the GG Meetings of the Camboriú River Basin Water Producer project, under the Technical Cooperation Agreement of 2012.

$\mathbf{A}$

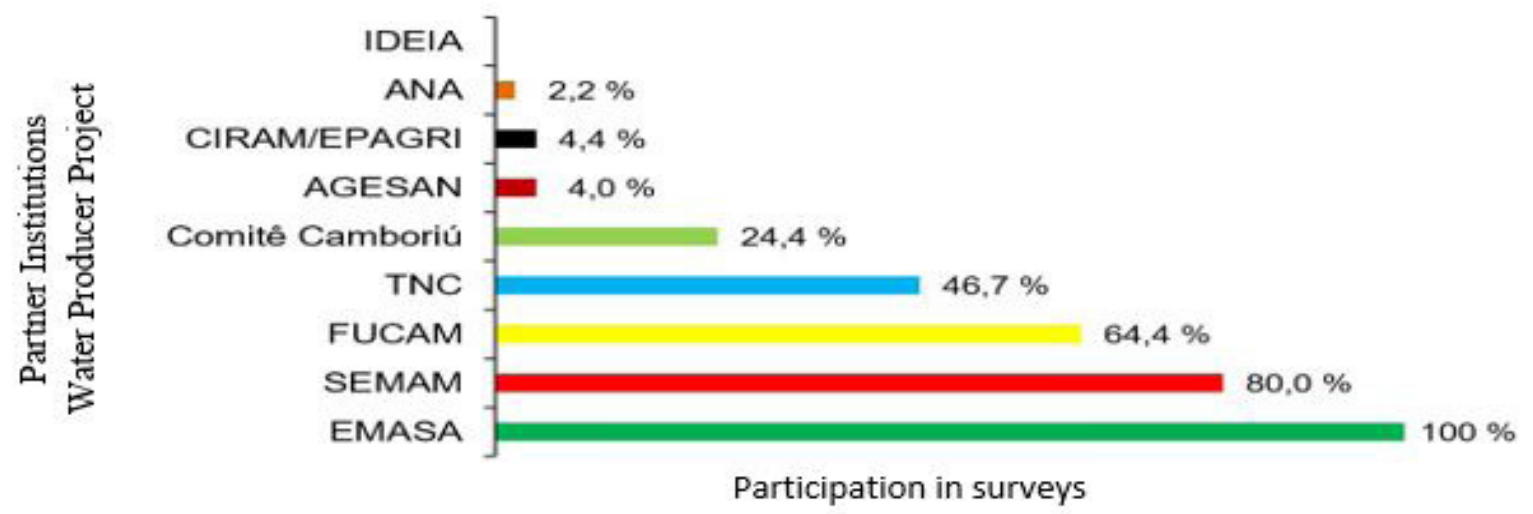

B

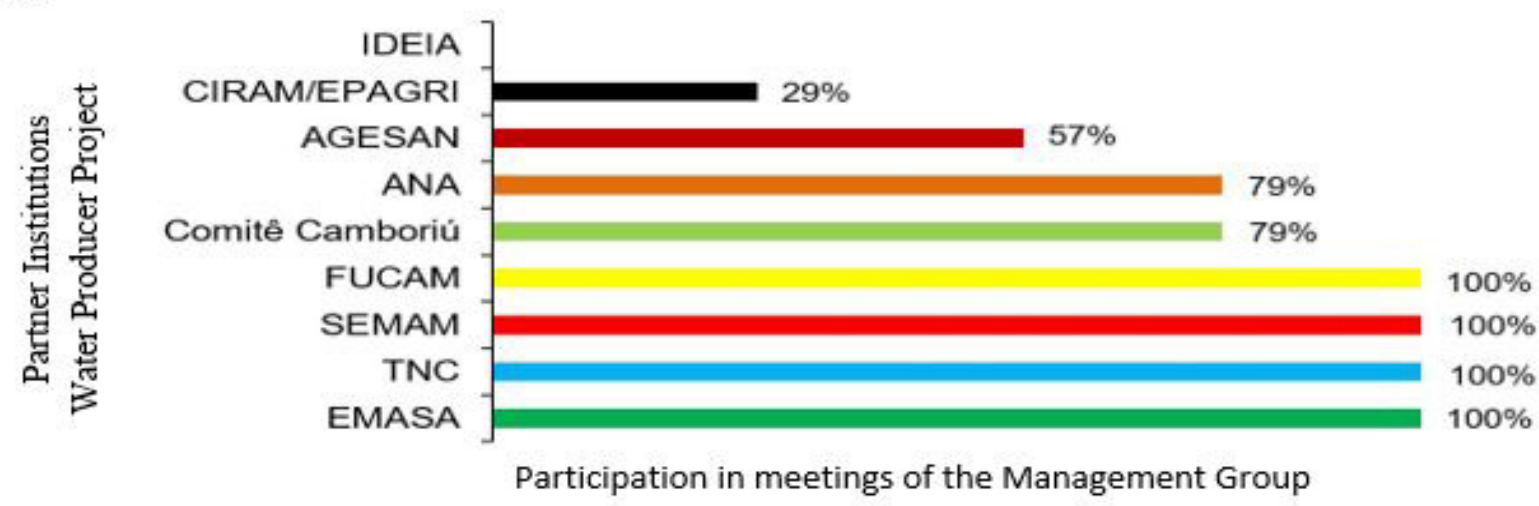

\section{Conclusion}

The Water Producer Projects can contribute to the regulation, increasing the quality and quantity of water in the areas where they operate. To measure the effectiveness of PAs, it is necessary to evaluate the achievement of the goals established in the contracts between the Grantor and the Rural Landowners, the high renewal rate of the $81.25 \%$ contracts is a good indication of the good performance of the PA project that was observed using the reports of surveys and in situ checks as instruments. The participation of practically $90 \%$ of the partner institutions in the decision-making meetings demonstrates the society's commitment to the PA project and its concern about water scarcity. Monitoring and permanent assessment of the PA are essential, as it provides greater transparency and corrections in the use of financial resources and management strategies.

\section{ACKNOWLEDGMENTS}

The Municipal Water and Sanitation Company of Camboriú (EMASA, in the Portuguese acronym), in particular the Environmental Engineer Rafaela Comparim Santos, Leonardo Petrocelli Garcez and other contributors of the institution, for having provided necessary information for the completion of this study. The present work was developed with the support of the Coordination of Improvement of Higher Education Personnel - Brazil (CAPES) - Funding code 001. 


\section{REFERENCES}

Antunes PP, Carvalho RM, Espinoza HWF. 2017. Analysis of the landscape structure of the Braço River sub-basin as subsidy for a project for payment for environmental services in the city of Camboriú, Santa Catarina, Brazil. Revisit Society \& Nature, 29(1):79-89.

Antunes A, Schwingel PR, Burliga ALM, Urban S. 2007. Composition of the phytoplankton of the BHRC (SC, Brazil) during the summer of 2005. Braz. J. Aqu. Sci. Technol., 11(2):33-43.

Benetti CJ, Ft-Rez Bilbao, Garrido J. 2012. Macroinvertebrates as indicators of water quality in running waters: 10 years of research in rivers with different degrees of anthropogenic impacts. In: Ecological Water Quality-Water Treatment and Reuse. Rijeka, Croatia, p. 95-120.

Bernardes C, Junior WWS. 2010. Payment for Environmental Services: Brazilian Experiences related to Water. Florianópolis, $11 \mathrm{p}$.

Blanco JT, Wunder S, Navarrete F. 2008. La experience end Colombia paid schemes for services with environmental impacts and natural resources in Colombia, $109 \mathrm{p}$.

Brasil, 2012. Lei no 12.651, de 25 de maio de 2012. Dispõe sobre a proteção da vegetação nativa. Diário Oficial da União.

Everard M, Powell A. 2002. Rivers as living systems. In: Aquatic Conservation: Marine and Freshwater Ecosystems, v. 12, ed. 4, p. 329-337.

Group Boticário Foundation, The Nature Conservancy of Brazil, Ministry of the Environment and Deutsche Gesellschaft fur International e Zusammenarbeit (FGB/TNC/MMA/GIZ). 2017. Payment for Environmental Services (PES). Guide for the Formulation of Statutory and Municipal Public Policies of Payment for Environmental Services, 77 p.

Ministry of the Environment (MMA). 2011. Payments for Environmental Services in the Atlantic Forest - lessons learned and challenges. Brasília, $272 \mathrm{p}$.

National Water Agency (ANA). 2012. Operational Manual. Water Producer Program. Brasília, 66 p.

National Water Agency (ANA). 2008. Water Producer Program. Brasília, 23 p.

Santos PH. 2018. Evaluation of the Effectiveness of the Water Producer Project in the Camboriú River Watershed (SC), 148f. Dissertation (Master in Environmental Science and Technology) - University of Vale do Itajaí, Itajaí.

Santos PH, Schwingel PR. 2017. Proposal for procedures for inspection of Water Producer Projects: Camboriú River Basin - SC. Brazil. Brazilian Journal of Aquatic Science Technology, 21(1):1-3.

The Nature Conservancy (TNC). 2017. Analysis of the return on investment in watershed conservation. Theoretical reference and case study of the Camboriú River Water Producer project, Santa Catarina, Brazil, 50 p.

Victorino VIP. 2003. Monopoly, conflict and participation in the management of water resources. Environment \& Society, 6(2):47-68. 